\title{
Algoritma Regresi Linear pada Prediksi Permohonan Paten yang Terdaftar di Indonesia
}

\author{
Deny Novianti ${ }^{\mathrm{a} 1}$, Nicodias Palasara ${ }^{\mathrm{b} 2}$, Muhammad Qomaruddin ${ }^{\mathrm{c} 3}$ \\ ${ }^{a}$ Sistem Informasi, Universitas Bina Sarana Informatika \\ Jl. Kramat Raya No. 98, Senen - Jakarta Pusat \\ ${ }^{1}$ denynov.dov@bsi.ac.id \\ ${ }^{b}$ Sistem Informasi, Sekolah Tinggi Manajemen Informatika dan Komputer Nusa Mandiri \\ Jl. Jatiwaringin No. 02, Cipinang Melayu, Jakarta Timur \\ 2nico.ncp@nusamandiri.ac.id \\ ${ }^{c}$ Teknik Informatika, Sekolah Tinggi Manajemen Informatika dan Komputer Nusa Mandiri \\ Jl. Jatiwaringin No. 02, Cipinang Melayu, Jakarta Timur \\ 3muhammad.mqn@nusamandiri.ac.id
}

\begin{abstract}
Abstrak
Paten merupakan salah satu bagian dari Hak Kekayaan Intelektual (HKI). Dan dengan semakin banyaknya paten yang mendaftar dari berbagai negara dari tahun ke tahun, membuat peluang untuk dapat diprediksi pendaftarannya pada tahun berikutnya. Prediksi merupakan dugaan atau prediksi mengenai terjadinya suatu kejadian atau peristiwa di waktu yang akan datang. Prediksi bisa bersifat kualitatif (tidak berbentuk angka) maupun kuantitatif (berbentuk angka). Analisis regresi adalah suatu metode statistik yang mengamati hubungan antara variabel terikat $\mathrm{Y}$ dan serangkaian variabel bebas $\mathrm{X} 1, \ldots, \mathrm{Xp}$. Tujuan dari metode ini adalah untuk memprediksi nilai $Y$ untuk nilai X yang diberikan. penelitian ini di dapatkan bahwa metode linear regresi layak dan efektif untuk memprediksi pendaftaran paten untuk tahun selanjutnya berdasarkan data pendaftaran dari tahun 2014 sampai tahun 2018. Pada penelitian didapatkan bahwa metode linear regresi layak dan efektif untuk memprediksi pendaftaran paten untuk tahun selanjutnya berdasarkan data pendaftaran dari tahun 2014 sampai tahun 2018. Analisis hasil prediksi data paten dipengaruhi oleh data dari tahun 2015 dan tahun 2017. Data dari hasil prediksi ini dapat digunakan sebagai dasar untuk persiapan jumlah paten yang harus diperiksa dan diterbitkan oleh Direktorat Jenderal Kekayaan Intelektual.
\end{abstract}

Kata kunci: Prediksi,Regresi Linear, HKI, Paten, Data Mining

\section{Linear Regression Algorithm for Prediction of Patent Applications Registered in Indonesia}

\begin{abstract}
Patents are a part of Intellectual Property Rights (HKI). And with the increasing number of patents registered from various countries from year to year creates predictable opportunities for registration in the following year. Prediction is a prediction or prediction regarding the occurrence of an event or event in the future. Predictions can be qualitative (not in the form of numbers) or quantitative (in numbers). Regression analysis is a statistical method that examines the relationship between the dependent variable $Y$ and a series of independent variables $\mathrm{X} 1, \ldots, \mathrm{Xp}$. The purpose of this method is to predict the $\mathrm{Y}$ value for a given $\mathrm{X}$ value. In this study, it was found that the linear regression method was feasible and effective for predicting patent registration for the following year based on registration data from 2014 to 2018. The study found that the linear regression method was feasible and effective for predicting patent registration for the next year based on registration data from the year 2014 to 2018. Analysis of the prediction results of patent data is influenced by data from 2015 and 2017. The data from these prediction results can be used as the basis for the preparation of the number of patents that must be examined and issued by the Directorate General of Intellectual Property.
\end{abstract}

Keywords: Predictions, Linear Regression, HKI, Patents, Data Mining

\section{Pendahuluan}

Istilah paten sering kita dengar banyak dipakai oleh masyarakat luas; dan bahkan tak jarang disalah-pahami sebagai padanan dari istilah "hak kekayaan intelektual" itu sendiri. Namun sesungguhnya, paten hanyalah salah-satu dari sekian banyak bentuk perlindungan HKI. Paten adalah perlindungan HKI bagi karya intelektual yang bersifat 
teknologi, atau dikenal juga dengan istilah invensi, dan mengandung pemecahan / solusi teknis terhadap masalah yang terdapat pada teknologi yang telah ada sebelumnya [1], Perkembangan IPTEK sebuah segara tidak terlepas dari peran aktif dari proses berpikir manusia untuk mengetahui segala sesuatu di bumi ini (sebagai hasil ciptaan Tuhan) melalui penelitian-penelitian yang kreatif dan inovatif [2].

Dalam penelitian ini digunakan tiga macam jenis paten, yaitu paten biasa, paten sederhana, dan paten pct nasional. Secara umum, hal-hal ataupun subjek yang dapat dipatenkan adalah Proses, Mesin, Barang (yang di produksi serta dapat digunakan), Metode Bisnis, Perangkat Lunak, Teknik Medis, Teknik Olahraga, dan lain sebagainya. Dan untuk di Indonesia, syarat hasil penemuan yang dapat dipatenkan yaitu Invensi memiliki aspek kebaruan, atau dengan kata lain invensi itu belum pernah diungkapkan sebelumnya, Invensi harus mengandung langkah inventif, yaitu mengandung langkah yang tidak diduga sebelumnya bagi seseorang dengan keahlian tertentu di bidang teknik, Invensi dapat diterapkan dalam industri [3].

Dari tahun ke tahun, telah banyak negara yang mendaftarkan patennya di Indonesia berdasarkan jenis paten yang ada. Ada yang mengalami kenaikan di setiap tahunnya, ada juga yang mengalami penurunan ataupun stabil dalam pendaftarannya.

Regresi Linear merupakan salah satu metode yang dapat digunakan untuk prediksi. Regresi linier merupakan satu metode prediksi yang menggunakan garis lurus untuk menggambarkan hubungan diantara dua variabel (atau lebih) [4]. Data Mining memiliki beberapa pandangan, seperti knowledge discover ataupun pattern recog-nition. Kedua istilah tersebut sebenarnya memiliki ketepatan masing-masing, istilah knowledge discovery atau penemuan pengetahuan tepat karna digunakan karena tujuan utama dari data mining memang untuk mendapat pengetahuan yang masih tersembunyi di dalam bongkahan data [3].

Prediksi merupakan dugaan atau prediksi mengenai terjadinya suatu kejadian atau peristiwa di waktu yang akan datang. Prediksi bisa bersifat kualitatif (tidak berbentuk angka) maupun kuantitatif (berbentuk angka). Prediksi kualitatif sulit dilakukan untuk memperoleh hasil yang baik karena variabelnya sangat relatif sifatnya. Prediksi kuantitatif dibagi dua yaitu: prediksi tunggal (point prediction) dan prediksi selang (interval prediction). Prediksi tunggal terdiri dari satu nilai, sedangkan prediksi selang terdiri dari beberapa nilai, berupa suatu selang (interval) yang dibatasi oleh nilai batas bawah (prediksi batas bawah) dan batas atas (prediksi tinggi) [5].

Analisis regresi adalah suatu metode statistik yang mengamati hubungan antara variabel terikat $\mathrm{Y}$ dan serangkaian variabel bebas $\mathrm{X} 1, \ldots, \mathrm{Xp}$. Tujuan dari metode ini adalah untuk memprediksi nilai $\mathrm{Y}$ untuk nilai $\mathrm{X}$ yang diberikan. Model regresi linier sederhana adalah model regresi yang paling sederhana yang hanya memiliki satu variabel bebas $\mathrm{X}$. Analisis regresi memiliki beberapa kegunaan, salah satunya untuk melakukan prediksi terhadap variabel terikat Y [4]. Persamaan untuk model regresi linier sederhana adalah sebagai berikut:

$$
\mathrm{Y}=\mathrm{a}+\mathrm{bX}
$$

$\mathrm{Y}$ adalah variabel terikat yang diramalkan, $\mathrm{X}$ adalah variabel bebas, a adalah intercept, yaitu nilai $\mathrm{Y}$ pada saat $\mathrm{X}=0$, dan $\mathrm{b}$ adalah slope, yaitu perubahan rata-rata $\mathrm{Y}$ terhadap perubahan satu unit $\mathrm{X}$. Koefisien a dan $\mathrm{b}$ adalah koefisien regresi dimana nilai $a$ dan $b$ dapat dicari menggunakan persamaan berikut. Nilai a adalah slope, $b$ adalah intercep dan $\mathrm{n}$ adalah banyaknya data yang digunakan dalam perhitungan.

$$
\begin{aligned}
\mathrm{b}= & \mathrm{n}(\Sigma \mathrm{xy})-(\Sigma \mathrm{x})(\Sigma \mathrm{y}) \\
& \mathrm{n}(\Sigma \mathrm{x} 2)-(\Sigma \mathrm{x}) 2 \\
\mathrm{a}= & \Sigma \mathrm{y}-\mathrm{b}(\Sigma \mathrm{x})
\end{aligned}
$$$$
\mathrm{n}
$$

Metode Regresi Linear telah banyak digunakan dalam berbagai penelitian, seperti yang pernah dilakukan menerapkan algoritma regresi linear untuk memprediksi akurasi pengiriman produk menggunakan administrasi, produksi dan pengiriman sebagai atribut yang akan dibandingkan dengan target yang ada yang merupakan hasil dari perjanjian antara perusahaan dan pelanggan digunakan sebagai variabel dependen[6].

Dari studi ini ditemukan bahwa metode linear layak dan efektif untuk memprediksi administrasi, produksi dan pengiriman target untuk akurasi pengiriman produk di perusahaan berdasarkan data pelatihan dari Januari 2018 sampai Juni 2018 dan diuji dengan Juli data 2018. Kemudian penelitian yang dilakukan oleh [7], Prediksi dapat dilakukan dengan berbagai metode, salah satunya metode regresi linier sederhana. Penelitian ini dilakukan dengan tujuan untuk membangun sistem informasi geografis yang dapat menyajikan hasil prediksi pemakaian air bersih kota Bandar Lampung dalam wilayah pelayanan PDAM Way Rilau Kota Bandar Lampung. Data pada penelitian ini diperoleh dari PDAM Way Rilau Kota Bandar Lampung. Hasil keseluruhan pengujian menunjukkan bahwa sistem informasi geografis penyebaran dan prediksi jumlah penduduk telah sesuai baik dari segi fungsionalitasnya, maupun dari segi interaksi sistem dengan pengguna.

Selanjutnya penelitian oleh [8], Salah satu faktor yang sangat menentukan dalam membuat rencana operasi sistem tenaga listriktersebut adalah prediksi beban listrik yang akan ditanggung oleh sistem tenagalistik yang bersangkutan. Penelitian ini bertujuan untuk memprediksi kebutuhan energi listrik di Provinsi Lampung hingga Tahun 2030, diharapkan dapatdijadikan sebagai masukkan dalam melakukan perencanaan pembangunan sistem tenaga listrik. Prediksi kebutuhan energi listrik Lampung dibagi menjadi 4 sektor yaitu : sektor rumah tangga, bisnis, publik, dan industri. Proses perancanganprediksi kebutuhan energi listrik menggunakan 6 variabel dan dibagi menjadi 2 parameter, yaitu: parameter ekonomi (produk domestik regional bruto, jumlahpenduduk, jumlah rumah tangga) dan parameter listrik (rasio elektrifikasi, faktor beban, losses). Dengan menggunakan metode regresi linier untuk memprediksivariabel-variabel di atas, diperoleh hasil prediksi daya listrik tersambung totalpada tahun 2028 sebesar 2.841,78 MVA (rata-rata pertumbuhannya sebesar $2,38 \%$ ), dan konsumsi energi 
listrik pada tahun 2023 sebesar 5.934,98 Gwh (rata-rata pertumbuhannya sebesar $3,83 \%$ ).

Lalu penelitian yang dilakukan oleh [9], Analisis regresi merupakan analisis yang bertujuan untuk menentukan model yang paling sesuai untuk pasangan data serta dapat digunakan untuk membuat model dan menyelidiki hubungan antara dua variabel atau lebih. Hasil persamaan matematika regresi yang mempengaruhi jumlah produksi adalah variabel kerusakan mesin (KM) dan harga bahan baku (HBB) serta jumlah tenaga kerja (JTK) nilai konstanta 500.308 menyatakan bahwa jika tidak ada variabel kerusakan mesin, harga bahan baku dan jumlah tenaga kerja, maka jumlah produksi sebesar 500.300. Dengan mengasumsikan diabaikannya variabel independen lainnya, jika kedua variabel (X1_KM) bernilai positif sebesar 47.869 dan (X2_HBB) bernilai positif sebesar 7.2700000, maka jumlah produksi meningkat sebesar $1 \%$, dan jika variable (X3_JTK) bernilai negatif -3.460 , jumlah produksi mengalami penurunan $1 \%$, sebesar 3.640.

Berikutnya penelitian yang dilakukan oleh [4], Pemanfaatan penelitian ini bertujuan untuk melakukan prediksi kebutuhan obat berdasarkan pesanan dan data penjualan. Proses prediksi dimulai dengan menentukan komponen $\mathrm{x}$ dan $\mathrm{y}$, kemudian mencari persamaan liniernya, menghitung persamaan linier dan mendapatkan persamaannya. Keluaran pada penelitian ini adalah sebuah prediksi yang ditampilkan oleh sistem sehingga dapat membantu distributor dalam melakukan prediksi untuk memenuhi kebutuhan obat. Berdasarkan hasil prediksi penjualan dengan nama item albothyle concentrate $10 \mathrm{ml}$ dengan angka di bawah atau di atas 19.662. Jika persamaan garis regresi bernilai minus maka hasil prediksinya akan dianggap 0.

Penelitian yang dilakukan oleh [10] Tujuan yang ingin dicapai adalah untuk mengetahuai apakah produksi kopi mengalami peningkatan atau penurunan dari waktu ke waktu. Untuk memenuhi kebutuhan kopi maka dilakukan prediksi dengan menggunakan Regresi linear sederhana atau Simple Regresi Linear yang merupakan salah satu metode statistik yang dipergunakan dalam produksi untuk melakukan peramalan ataupun prediksi tentang karakteristik kualitas maupun kuantitas. Simple Regresi Linear terdiri dari satu buah variabel bebas (x) dengan satu buah variabel terikat (y). Dengan melakukan prediksi menggunakan Metode Regresi Linear dapat memberikan informasi yang membantu para petani dan pemerintah dalam mengambil kebijakan guna meningkatkan produksi kopi di Kabupaten Manggarai. Hasil yang diperoleh dari penelitian ini yang melibatkan 5 periode yaitu dari tahun 2011-2015 nilai tertinggi pada tahun 2015 sebesar 1.537,38 ton dan nilai terendah pada tahun 2011 sebesar 1.109 . Setelah dilakukan pengujian menggunakan MSE dan MAPE di peroleh nilai MSE 43,112\% dan MAPE 20,001\% sehingga pengujian menggunakan MAPE jauh lebih baik dalam menghitung akurasi prediksi produksi kopi.

Pada penelitian yang dilakukan oleh[11] [12], Semakin banyaknya paten yang masuk dari berbagai Negara di Asia Tenggara, maka akan dapat diketahui kelompok Negara mana saja kah yang memiliki pendaftaran paten terbanyak selama 3 tahun terakhir. Pada penelitian ini K-Means digunakan untuk mengelompokkan Negara mana sajakah yang pendaftaran patennya tertinggi dan terendah.

Lalu penelitian yang dilakukan oleh[13], Pengelompokan karakteristik suatu daerah berdasarkan kemiskinan indikator, sehingga pemerintah dapat dengan tepat dan cepat mengambil kebijakan penanggulangan kemiskinan di suatu daerah. Metode yang digunakan dalam hal ini. Penelitian menggunakan metode K-Means Clustering. Pengelompokan metode dipilih karena metode ini memiliki kemampuan untuk mengklasifikasikan data dalam jumlah besar dengan waktu proses yang lebih cepat secara efisien.

Berikutnya penelitian[14], bahwa Dengan melakukan prediksi menggunakan MetodeRegresi Linear dapat memberikan informasi yang membantu para petani dan pemerintah dalam mengambil kebijakan guna meningkatkan produksi kopi di Kabupaten Manggarai. Hasil yang diperoleh dari penelitian ini yang melibatkan 5 periode yaitu dari tahun 2011-2015 nilai tertinggipada tahun 2015 sebesar 1.537,38 ton dan nilai terendah pada tahun 2011 sebesar 1.109

Penelitian dari [15], Tujuan dari penelitian adalah Menerapkan metode Regresi Linear dalam menentukan harga jual mobil bekas Toyota Avanza, Toyota Kijang Innova, dan Daihatsu Xenia berdasarkan jenis dan tipe, tahun pembuatan, harga beli baru dan kisaran harga jual mobil bekas. sistem yang dibangun untuk membantu memprediksi harga jual mobil bekas dapat bermanfaat dan baik. Sistem ini menggunakan metode regresi linear untuk memprediksi harga jual mobil. Metode regresi linear diterapkan pada data ketiga mobil tersebut dan menghasilkan persamaan regresi linear. Persamaan tersebut selanjutnya diuji nilai akurasinya sebesar $80 \%$.

Berdasarkan data tersebut, maka dapat dibuatkan sebuah prediksi yang digunakan untuk mengetahui berapakah banyak paten yang akan di daftarkan di tahun selanjutnya. Ini bertujuan untuk memberikan informasi untuk persiapan jumlah paten yang harus diperiksa dan diterbitkan oleh Direktorat Jenderal Kekayaan Intelektual. Dengan menggunakan negara dan jenis paten sebagai variabel independen, serta tahun yang menjadi pedoman dalam memprediksi perubahan dalam pendaftaran paten digunakan sebagai variabel dependen.

\section{Metodologi Penelitian}

Data penelitian ini menggunakan data dari data base KI tahun 2016-2018.

\section{A. Knowledge Discovery In Database (KDD)}

KDD adalah salah satu metode yang dapat digunakan untuk memperoleh pengetahuan yang berasal dari database yang tersedia. Untuk lebih jelasnya, berikut gambaran dari metode KDD [11].

1) Selection: Pada tahap ini, data di dapat dari database KI. Dalam penelitian ini, data yang diambil dimulai dari periode tahun 2015 sampai dengan tahun 2018 dengan total data sebanyak 210 data.

2) Preprocessing Data Cleaning: Pada tahap pembersihan data yang dilakukan termasuk menghapus 
duplikasi data, lalu memeriksa inkonsistensi data dan kesalahan pada data. Data yang digunakan dalam penelitian ini pada awalnya sebanyak 209 data menjadi 204 data.

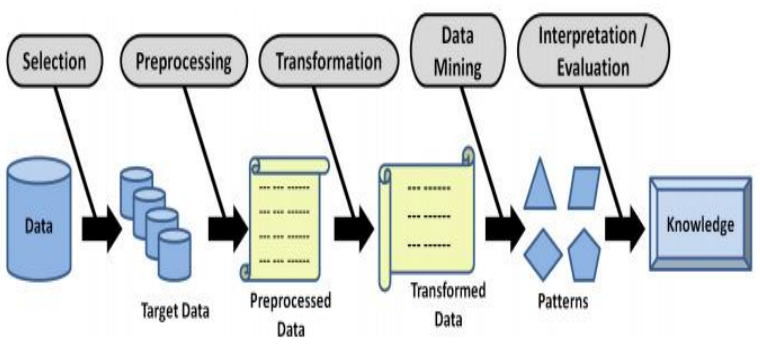

Gambar 1. Metode knowledge discovery in database

3) Transformation: Setelah melalui tahapan preProcessing sebanyak 204 data terdiri dari 5 atribut, yaitu tahun 2015, 2016, 2017, dan tahun 2018.

4) Data mining: Penelitian ini menggunakan algoritma regresi linear. Data yang telah melalui tahap transformasi lalu diproses di Rapid Miner menggunakan algoritma regresi linear.

5) Evaluation: InterpretationPola yang dihasilkan dari proses regresi linear bentuk informasi yang mudah dimengerti dan memeriksa apakah pola atau informasi yang ditemukan bertentangan dengan fakta atau hipotesis sebelumnya. Dan diharapkan penelitian ini dapat membantu mengetahui seberapa besar pendaftaran untuk di tahun selanjutnya.

\section{HASIL DAN PEMBAHASAN}

Dalam penelitian ini menggunakan perangkat lunak untuk menghasilkan data analisa dari algoritma regresi linear. Perangkat lunak yang digunakan adalah Rapidminer versi 8.0, untuk dapat menggunakan aplikasi ini kita perlu mempersiapkan data pendaftaran paten yang sudah melewati tahap pre-processing dan data transformasi data ke dalam format Excel. Berikut ini adalah contoh data pendaftaran paten setelah melalui tahap seleksi dalam Tabel I.

TABEL I

SAMPLE Data PENDAFTARAN PATEN

\begin{tabular}{|l|l|l|l|l|l|}
\hline Negara+Jenis & $\mathbf{2 0 1 4}$ & $\mathbf{2 0 1 5}$ & $\mathbf{2 0 1 6}$ & $\mathbf{2 0 1 7}$ & $\mathbf{2 0 1 8}$ \\
\hline Taiwan_Paten & 387 & 339 & 80 & 296 & 488 \\
\hline $\begin{array}{l}\text { Antigua and } \\
\text { Barbuda_Paten }\end{array}$ & 0 & 0 & 0 & 0 & 10 \\
\hline Argentina_Paten & 3 & 0 & 0 & 6 & 0 \\
\hline Armenia_Paten & 0 & 0 & 0 & 0 & 2 \\
\hline Australia_Paten & 1092 & 725 & 1553 & 1020 & 776 \\
\hline Negara+Jenis & $\mathbf{2 0 1 4}$ & $\mathbf{2 0 1 5}$ & $\mathbf{2 0 1 6}$ & $\mathbf{2 0 1 7}$ & $\mathbf{2 0 1 8}$ \\
\hline Austria_Paten & 466 & 242 & 320 & 171 & 136 \\
\hline Azerbaijan_Paten & 0 & 0 & 0 & 0 & 7 \\
\hline Bahamas_Paten & 0 & 4 & 26 & 0 & 1 \\
\hline
\end{tabular}

\begin{tabular}{|l|l|l|l|l|l|}
\hline Barbados_Paten & 3 & 0 & 0 & 0 & 0 \\
\hline Belarus_Paten & 0 & 1 & 0 & 0 & 0 \\
\hline Belgium_Paten & 412 & 1123 & 1114 & 1088 & 1344 \\
\hline
\end{tabular}

Pada Tabel I diatas dengan metode Knowledge Discovery In Database (KDD) setelah melakukan pemilihan data, perlu dilakukan tahapan data pre-processing dan transformasi data. Dari data pendaftaran paten, data asli sebanyak 209 data menjadi 204 data.

Berikut adalah data yang telah ditentukan atribut dan komponen X, Y yang akan diproses pada Rapidminer seperti yang ditunjukkan pada Tabel II.

TABEL II

SAMPLE DATA YANG DIGUNAKAN DALAM PENELITIAN

\begin{tabular}{|c|c|c|c|c|}
\hline $\mathbf{2 0 1 4}$ & $\mathbf{2 0 1 5}$ & $\mathbf{2 0 1 6}$ & $\mathbf{2 0 1 7}$ & $\mathbf{2 0 1 8}$ \\
\hline 387 & 339 & 80 & 296 & 488 \\
\hline 0 & 0 & 0 & 0 & 10 \\
\hline 3 & 0 & 0 & 6 & 0 \\
\hline 0 & 0 & 0 & 0 & 2 \\
\hline 1092 & 725 & 1553 & 1020 & 776 \\
\hline 466 & 242 & 320 & 171 & 136 \\
\hline 0 & 0 & 0 & 0 & 7 \\
\hline 0 & 4 & 26 & 0 & 1 \\
\hline 3 & 0 & 0 & 0 & 0 \\
\hline 0 & 1 & 0 & 0 & 0 \\
\hline 412 & 1123 & 1114 & 1088 & 1344 \\
\hline
\end{tabular}

Berdasarkan pengolahan data menggunakan Rapidminer versi 8,0 , dapat dilihat output dari hasil pengolahan data yang ditemukan di Gambar 2.

\begin{tabular}{|c|c|c|c|c|c|c|c|}
\hline Altibute & Coefficient & Sthe Eror & Sydachefficient & Tolerance & t. Stat & p.Value & cole \\
\hline 2015 & 0.566 & 0.068 & 0.497 & 0.609 & 8410 & 0.000 & "ntt \\
\hline 2017 & 0.72 & 0.009 & 0.489 & 0.60 & 8280 & 0.000 & $\mathrm{mtt}$ \\
\hline (ntereeper) & 15.301 & 39.445 & $?$ & $?$ & 0389 & 0.098 & \\
\hline
\end{tabular}

Gambar 2. Data hasil dari rapid miner

Dari output yang dihasilkan dapat dirumuskan sebuah persamaan regresi matematika tahun 2015 dan tahun 2017 variabel sebagai berikut:

$$
\text { Prediction }(\mathrm{yi})=\text { Intercept }+\mathrm{b} 1 \mathrm{X} 1+\mathrm{b} 2 \mathrm{X} 2+\mathrm{b} 3 \mathrm{X} 3
$$$$
\text { Prediction }(y i)=15.301+(0.556 \times \text { tahun } 2015)+
$$

$$
\text { (0.572 } \mathrm{x} \text { tahun 2017) }
$$

Nilai konstan 15.301 menyatakan bahwa jika tidak ada variabel 2015 dan 2017, maka target pendaftaran adalah sebanyak 15.301. Koefisien untuk variabel tahun 2016 (X1) adalah positif pada 0,556 menunjukkan bahwa jika variabel independen lainnya tetap dan tahun 2015 meningkat $0.5 \%$, 
target pendaftaran akan meningkat dengan 0,556. Koefisien untuk variabel tahun 2017 (X2) memiliki nilai positif dari 0.572 menunjukkan bahwa jika variabel independen lainnya adalah nilai tetap dan tahun 2017 meningkat sebesar $0.5 \%$, target pendaftaran akan meningkat dengan 0.572. Dari persamaan di atas, dapat dihasilkan data seperti pada Gambar 3.

\begin{tabular}{|l|l|l|l|l|l|l|}
\hline Negara+Jenis & 2018 & prediction(2... & 2014 & 2015 & 2016 & 2017 \\
\hline Taiwan_Paten & 488 & 377.574 & 387 & 339 & 80 & 296 \\
\hline Canada_Paten & 634 & 1030.598 & 1303 & 1162 & 767 & 638 \\
\hline China_Paten & 3109 & 3149.653 & 2185 & 2064 & 2286 & 3462 \\
\hline Colombia_P... & 1 & 24.145 & 24 & 8 & 2 & 0 \\
\hline Democratic_... & 0 & 22.567 & 0 & 0 & 0 & 5 \\
\hline Ecuado__Pat... & 4 & 19.702 & 1 & 0 & 0 & 0 \\
\hline Egypt_Paten & 0 & 19.702 & 0 & 0 & 2 & 0 \\
\hline Greece_Paten & 2 & 48.351 & 0 & 0 & 4 & 50 \\
\hline Mexico_Paten & 15 & 174.091 & 75 & 18 & 6 & 252 \\
\hline Sri_ank_Pa... & 0 & 21.385 & 0 & 2 & 0 & 1 \\
\hline
\end{tabular}

Gambar 3. Tabel hasil perhitungan regresi linier

Dari hasil perhitungan regresi linear di atas, dapat dilihat contohnya bahwa di kolom target (Y) tahun selanjutnya di dapatkan nilai prediksi 3 terbesar untuk negara Taiwan sebesar 377,574, Canada 1.030,598, dan China 3.149,653.

Berdasarkan hasil prediksi maka dapat ditarik kesimpulan hasil prediksi untuk Taiwan pendaftaran paten di tahun selanjutnya sebesar 378 paten, Canada sebesar 1.031 paten, dan China sebesar 3.150 paten.

Hasil dari rumus prediksi yang diperoleh, rumus prediksi diimplementasikan pada data testing sebanyak 20 data dan hasil yang diperoleh dari rumus prediksi memiliki akurasi $35.52 \%$. Dari penelitian sebelumnya, yang mengatakan bahwa regresi linier adalah layak dan efektif untuk penggunaan data yang mereka harus membuat prediksi. Demikian juga dengan penelitian ini dimana hasil yang diperoleh dalam pengujian data yang layak dan efektif untuk digunakan. Data hasil prediksi tidak dipengaruhi dari tahun 2014, 2016, dan 2018.

\section{KESIMPULAN}

Dari penelitian ini di dapatkan bahwa metode linear regresi layak dan efektif untuk memprediksi pendaftaran paten untuk tahun selanjutnya berdasarkan data pendaftaran dari tahun 2014 sampai tahun 2018. Analisis hasil prediksi data paten dipengaruhi oleh data dari tahun 2015 dan tahun 2017. Data dari hasil prediksi ini dapat digunakan sebagai dasar untuk persiapan jumlah paten yang harus diperiksa dan diterbitkan oleh Direktorat Jenderal Kekayaan Intelektual.

\section{DAFTAR PUSTAKA}

[1] HKI, "Paten - HKI.CO.ID."

[2] K. Hidayah, "Perlindungan Hak Paten Dalam Kajian Hukum Islam Dan Peran Umat Islam Dalam Bidang Iptek," J. Jure, vol. 4, no. 1 pp. 85-95, 2012, doi: 10.18860/j-fsh.v4i1.2160.
[3] A. Bastian et al., "No Title," no. 1, pp. 26-32.

[4] F. R. U. Pujo Sulardi, Tacbir Hendro, "Prediksi Kebutuhan Obat Menggunakan Regresi Linier,” Snatif, pp. 153-160, 2017, doi: 10.2298/PAN0903301G.

[5] M. H. Adiya and Y. Desnelita, "Jurnal Nasional Teknologi dan Sistem Informasi Penerapan Algoritma K-Means Untuk Clustering Data Obat-Obatan Pada RSUD Pekanbaru," vol. 01, pp. 17-24, 2019.

[6] W. Gata, H. B. Novitasari, R. Nurfalah, R. Hernawati, and M. J Shidiq, "Analysis of Regression Algorithm to Predict Administration , Production , and Delivery to Accuracy of Delivery of Products in Cosmetic Industry."

[7] A. Hijriani, K. Muludi, and E. A. Andini, "Implementasi Metode Regresi Linier Sederhana Pada Penyajian Hasil Prediksi Pemakaian Air Bersih Pdam Way Rilau Kota Bandar Lampung Dengan Sistem Informasi Geofrafis," Inform. Mulawarman J. Ilm. Ilmu Komput., vol. 11, no. 2, p. 37, 2016, doi: 10.30872/jim.v11i2.212.

[8] M. Syafruddin, H. Lukmanul Hakim, dan D. Dikpride, "Metode Regresi Linier Untuk Prediksi Kebutuhan Energi Listrik Jangka Panjang (Studi Kasus Provinsi Lampung)," J. Inform. dan Tek. Elektro Terap., vol. 2, no. 2, 2014.

[9] S. Sulistyono and W. Sulistiyowati, "Peramalan Produksi dengan Metode Regresi Linier Berganda," PROZIMA (Productivity, Optim Manuf. Syst. Eng., vol. 1, no. 2, p. 82, 2018, doi: 10.21070/prozima.v1i2.1350.

[10] P. Katemba and R. K. Djoh, "Prediksi Tingkat Produksi Kopi Menggunakan Regresi Linear," J. Ilm. FLASH, vol. 3, no. 1, pp. 42-51, 2017.

[11] F. Gullo, "From Patterns in Data to Knowledge Discovery: What Data Mining Can Do,” Phys. Procedia, vol. 62, pp. 18-22, 2015, doi: 10.1016/j.phpro.2015.02.005.

[12] D. Novianti and N. Palasara, "Klasterisasi Negara Pendaftar Paten Di Indonesia Menggunakan K-Means," Sistemasi, vol. 8, no. 3, p. 446, 2019, doi: 10.32520/stmsi.v8i3.541.

[13] N. I. Febianto and N. Palasara, "Analisa Clustering K-Means Pada Data Informasi Kemiskinan Di Jawa Barat Tahun 2018," J. Sisfokom (Sistem Inf. dan Komputer), vol. 8, no. 2, p. 130, 2019, doi: 10.32736/sisfokom.v8i2.653.

[14] P. Katemba and R. K. Djoh, "Prediksi Tingkat Produksi Kopi Menggunakan Regresi Linear," J. Ilm. FLASH, vol. 3, no. 1, pp. 42-51, 2017.

[15] M. Mona, J. Kekenusa, and J. Prang, "Penggunaan Regresi Linear Berganda untuk Menganalisis Pendapatan Petani Kelapa. Studi Kasus: Petani Kelapa Di Desa Beo, Kecamatan Beo Kabupaten Talaud," d'CARTESIAN, vol. 4, no. 2, p. 196, 2015, doi: 10.35799/dc.4.2.2015.9211. 